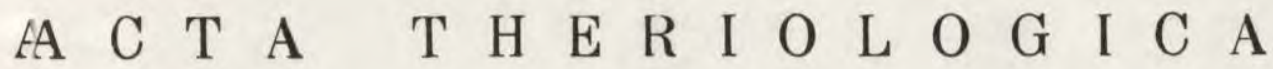 \\ WOL. XIII, 29: 461-482.

Tadeusz BUCHALCZYK and Zdzisław PUCEK

\section{Estimation of the Numbers of Microtus oeconomus Using the Standard Minimum Method*)}

[With 6 Tables and 9 Figs.]

\begin{abstract}
The aim of our study was to apply the removal method to estimating the population numbers of voles. Thus special attention was paid to analysis of factors involving removal of voles from the study area. Study area consisted of drained peat-bog, inside a forest, covered with plantations of trees and occupated by probably isolated population of root vole. Standard removal trapping was adopted, using snap traps and/or conical pitfalls (one at each station), placed at prebaited and unbaited sites. Six censuses were carried out during two year period. It was found that root voles never use a $100 \%$ of bait laid. There are no significant differences in removal rate of voles of different sex, but there is a tendency for the old animals of both sexes to be removed more quickly. Removal rate of shrews was very close to that of voles. Pre-baiting does not increased the removal rate of voles, although the numbers of voles caught in pitfalls are the same as in baited traps and are twice as great as in unbaited traps. It is suggested that removal for 5-day period from one hectare area is sufficient, in view of the fact that immigration into study area was not observed and that the number of voles per station is nearly constant throughout the whole study area. Mean estimates of the vole numbers, as calculated for six censuses from rectilinear regression closely agree with those obtained from truncated distribution, or with total number of voles removed (maximum - ca 130 voles/ha). Different estimations of population density can be obtained in the same area depending on the kind of trap used.
\end{abstract}

1. Introduction

2. Study area

3. Methods and materials

4. Removal of $M$. oeconomus from the study area: Analysis of factors involved

4.1. Bait consumption

4. . Effect of sex and the kind of trap used .

4.3. Influence of pre-baiting . . . . . . . . . . . . 469

4.4. Effect of time of day on the numbers of voles removed : 471

4.5. Distribution of captures throughout the study area . . . . . . 472

4.6. Comparison of removal rate of M. oeconomus and Sorex araneus . 473

** This study was carried out under the Small Mammal Project of International Bicological Programme in Poland. 
5. Effect of the size of the study area on number of voles removed per trap station

6. Estimation of numbers of voles

7. Discussion

References.

Streszczenie

\section{INTRODUCTION}

The Standard Minimum method as described by Grodziński, Pucek and Ryszkowski (1966) is adapted to estimating the number of rodents in forest ecosystems, particularly in relation to those species which are readily caught in baited snap traps (e.g. Clethrionomys glareolus, Apodemus flavicollis). This method was recommended as a standard comparative technique for estimating the number of rodents for the purpose of IBP (Ryszkowski \& Petrusewicz, 1967). The method cannot of course be universal and may require certain modifications when used for other species of small mammals (e. g. shrews, other voles, etc.).

Attempts have been made at applying the Standard Minimum (SM) method for ascertaining the numbers of insectivores (A ulak, 1967), but a decrease in the numbers of these mammals caught on successive days of capture and removal was not always obtained. In order to achieve trapping and removal of insectivores one metal cone (pitfall) in addition to two snap traps was placed on each of the stations of the trapping area. Soricidae, as we know, are only caught in small numbers in snap traps, particularly during the summer. Live traps were successfully used for the SM method instead of snap traps, when live animals were required for special purposes.

Since 1966 we have been examining an (probably) isolated population of Microtus oeconomus (P allas, 1776), living in a drained Sphagnum bog inside a forest. Investigations were made of bioenergetics and reproductive biology of $M$. oeconomus, and also into the question of the succession of forest species of small mammals in this newly planted area. Sumaries of the initial results have already been published ( $\mathrm{B} \mathrm{u}$ chalczyk, 1967; Gę bczyńska, 1967).

The aim of the present paper is to describe an attempt made at applying the SM method to estimating the population numbers of this species of vole. Particular attention was paid during these studies to: (1) The analysis of factors involving removal of voles of different categories from the study area, using two types of trap, and (2) The size of the trapping area necessary to estimate their numbers. 


\section{STUDY AREA}

The study area consisted of a drained Sphagnum peat-bog, inside a forest and lying between wet (south and west) and dry (north and east) forests of the Augustów Forest area in north-east Poland. The peat-bog, called "Biele«, was drained in 1962, after which the Department of Water Management of the Forestry Research Institute (Warsaw) began making use of the area.

In 1963 experimental plantation were set up in the central part of the glade, 15 ha in area. These are of deciduous trees: birch, alder, ash; coniferous trees: pine and spruce, and mixed plantations of pine, spruce, birch, oak and maple in various numerical combinations. Each type of plantation occupies a belt $20 \mathrm{~m}$ wide (occasionally only $8 \mathrm{~m}$ ) running in a north-south direction. From the west and east the area is sheltered by luxurient willowbeds (osiers, Salix sp.) $40 \mathrm{~m}$ wide. The poplar plantation in the east part of the area had been killed by forest and was covered by dense herbaceous vegetation. Spruce trees several years old were planted there in the spring of 1968.

The area, 15 ha in extent, is surrounded on the south and east by cultivated grassland through which the main streem runs. The enclosed experimental area is dissected by three drainage ditches running from west to east. Different parts of the cultivated land are separated by access paths from 1.5 to $4 \mathrm{~m}$ in width up to $50 \mathrm{~m}$ long. The paths and sides of the ditches are covered with grass, which is partially mown in summer.

\section{METHODS AND MATERIALS}

Six censuses of the numbers of $M$. oeconomus were carried out by means of the SM method (cf. Grodziński et al., 1966) in different parts of 15 ha experimental area in 1966 and 1967. Several modifications of the standard method were introduced for this purpose, namely: (1) During the first phase of working the area pre-baiting was carried out for the first 3-7 days, using oat grains (SM 1-4, 1966) or oats and wick saturated with a mixture of flour fried in rape seed oil (SM 5-6, 1967). The same was used subsequently in the snap traps, (2) Snap traps were used for trapping (two at each station) or metal conical pitfalls (cones, one at each station and without bait). In 1967 we used a combination of the two types of traps, placed alternately, $i$. e. one pitfall (cone), two snap traps, one pitfall, etc., the first two stations having previously been baited, and the next two left unbaited. In this way half of all the pitfalls and snap traps were placed on pre-baited stations, and the other half on unbaited stations, (3) Traps were placed directly on places on which bait had praviously been laid out (SM 5-6). During SM $1-4$ the traps were either placed exactly on the pre-baited site or just by it, but not however more than $50 \mathrm{~cm}$ from this site, (4) Removal normally lasted 5-6 days, once only 4 days, and was twice prolonged to 8 and 10 days. Mammals were removed from the traps twice a day: in the early morning, always after sunrise, and in the evening, before dusk. The results of the two inspections were added, giving the trapping result for the given day.

SM 1 and SM 2 censuses were located on previously untouched areas (the areas overlapped each other only over a belt of about $60 \mathrm{~m}$ in breadth). The next censuses were made in an area on which similar removal of voles had been carried out two to three months previously. The longest period of snon-exploitation* of 


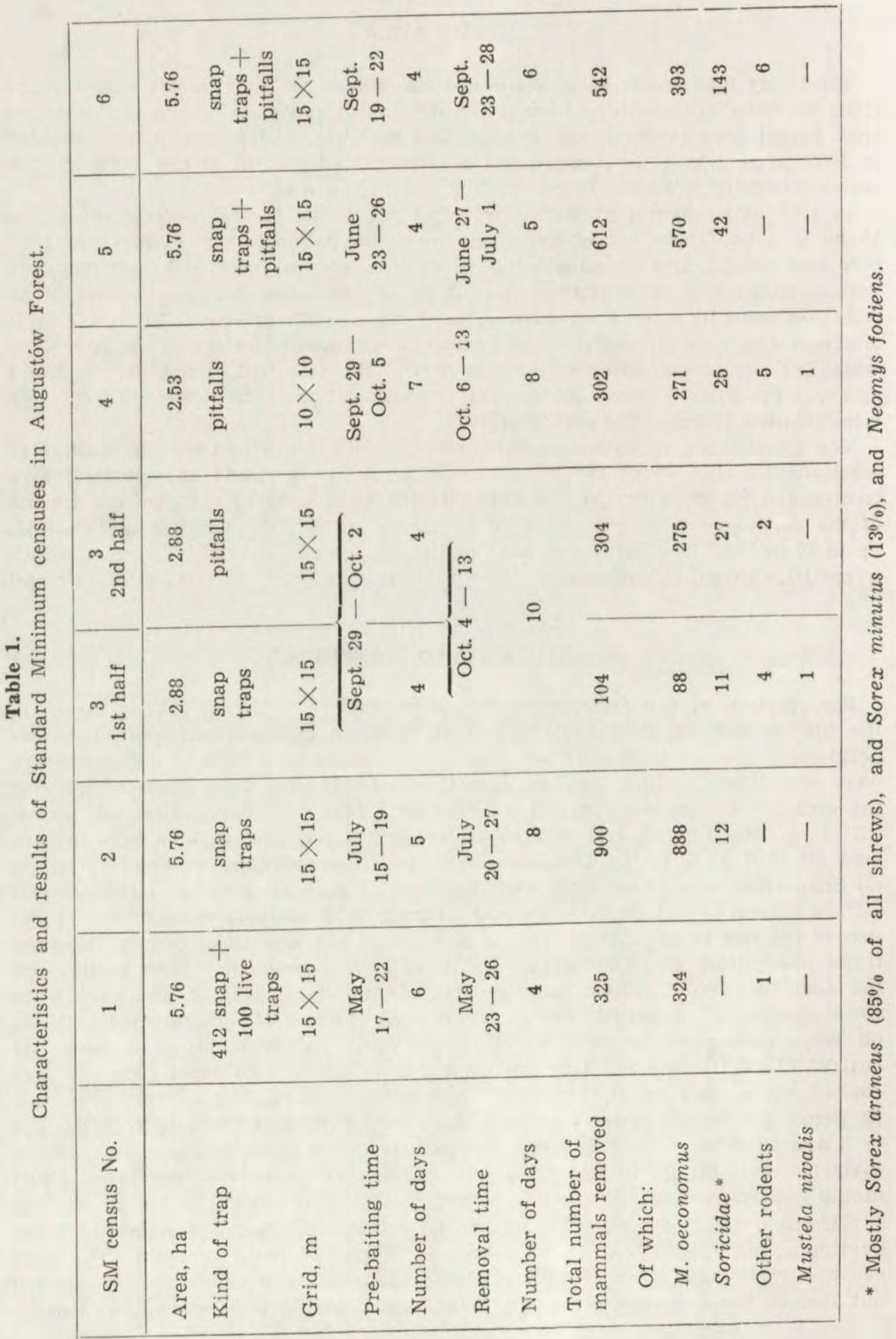


the area lasted from October 1966 to June 1967. Both 1967 censuses were carried out on exactly the same, permanently marked area, located in central part of forest plantations.

The working periods of the different areas, a description of these areas and the numbers of mammals obtained by trapping are illustrated in table 1.

The numbers of voles were estimated by means of two methods: (1) From a simple regression equation, illustrating the connection between daily capture and the total number of rodents previously caught (De Lury, 1947; Hayne, 1949; Grodziński et al., 1966). Calculations were always made for 5 days of trapping, except for SM-1, when trapping lasted 4 days only. (2) Calculations from truncated distributions for the first five, first three or last three days of trapping were also made ( $\mathrm{J}$ anion, Ryszkowski \& Wierzbowska, 1968).

\section{REMOVAL OF $M$. OECONOMUS FROM THE STUDY AREA: ANALYSIS OF FACTORS INVOLVED}

\subsection{Bait consumption}

Investigations were made to discover what connection there is between rate of bait consumption and the numbers of voles subsequently trapped. Out of the six SM censuses made, in no case was 100 per cent of the bait eaten, such as occurs in summer and autumn with forest rodents

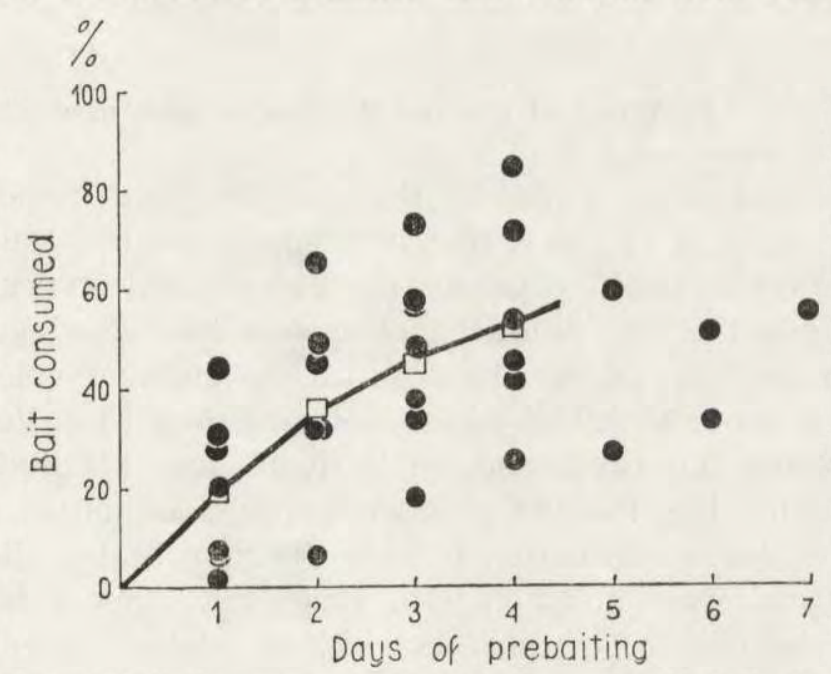

Fig. 1. Consumption of bait (in per cent of all stations at which the bait was laid) during the pre-baiting period. Points show the data for all censuses (cf. Table 1), line - averages for consecutive days.

(Grodziński et al., 1966). On the first day of the pre-baiting period consumption was (1) $6-44 \%$ and attained a maximum of $84 \%$ on the fourth day, with fluctuations from (25) 41 to 84 per cent. In cases in which pre-baiting period lasted longer, for six or seven days, maximum consumption of bait was respectively only 33 and 55 per cent (Fig. 1). 
Correlation coefficients between the number of days during which bait was eaten at a given station and the number of voles caught on this station calculated for the first four censuses (SM 1-4) are low or medium in three cases $(r=0.321-0.504)$ and in the remaining two not significant. It is difficult to point to distinct connections between population density, kind of trap and value of the correlation coefficient. When using snap traps or live traps these coefficients were significant in the two cases of low vole population (SM-1 and SM-3, first half), but not significant when large numbers were trapped (SM-2). When pitfalls were used, with medium population numbers (SM-3, second half, and SM-4) - a significant results was obtained once, and non-significant once.

These results indicate that the relation of $M$. oeconomus to the bait is undoubtedly different from that of forest rodents (cf. Grodzin nski et al., 1966). As in the case referred to, it is impossible to form an idea of the number of voles on the basis of intensivity of bait consumption. On the other hand bait consumption provides a good illustration of the spatial structure of populations of this species, and that as early as after 3 days of pre-baiting ( $\mathrm{Buchalczyk} \& \mathrm{Pucek}$, in preparation).

\subsection{Effect of sex and the kind of trap used}

Investigations were made of the trapping and removal rates for different categories of voles, that is, young animals (sexually inactive), old (active) males and females for the two principle types of trap, snap traps and pitfalls. The following categories were distinguished on the basis of an analysis of variations in body weight of voles: young, not fully grown, up to $35 \mathrm{~g}$, and adults weighing over $35 \mathrm{~g}$. Very few young animals exceed this limit, and similarly a few old individuals were found weighing less than $35 \mathrm{~g}$. Macroscopic examination of the genital system provided confirmation of this division. Males allocated to the "young " group were inactive, with small testes, whereas those in the "adult" group had large testes and well-developed vesiculae seminales, and were thus sexually active. Amoung the "young " females there was a certain percentage of individuals whose uteri indicated that they were sexually active (uterus thickened); These might even been in early pregnancy (preimplantation stages). They were therefore termed "young active females «. In the group weighing over $35 \mathrm{~g}$ there were occasional individuals with a thin uterus (particularly in the autumn period) which suggests that they had not yet taken part, or no longer took part, in reproduction. 
In order to ascertain the removal rate for individuals in the different categories calculations were made of the cumulative percentage of trapped animals to a given day, taking the number of animals obtained up to the 5 th day inclusive as $100 \%$. It is on the fifth day that the trapping curve drops in the various censuses to the level of one or a few individuals. In subsequent days the number of animals caught might however increase, particularly after rainfall. Cumulative percentages were calculated for the total numbers of voles caught on successive day in the different SM censuses. In some cases the results for only two SM were totalled in respect of the kind of trap (e. g. unbaited snap traps, unbaited pitfalls) and in others corresponding combinations SM-5 and SM-6 or whole standards (e.g. pre-baited traps - SM-2, 1/2 of SM-3, $1 / 4$ of SM-5 and $1 / 4$ of SM-6).

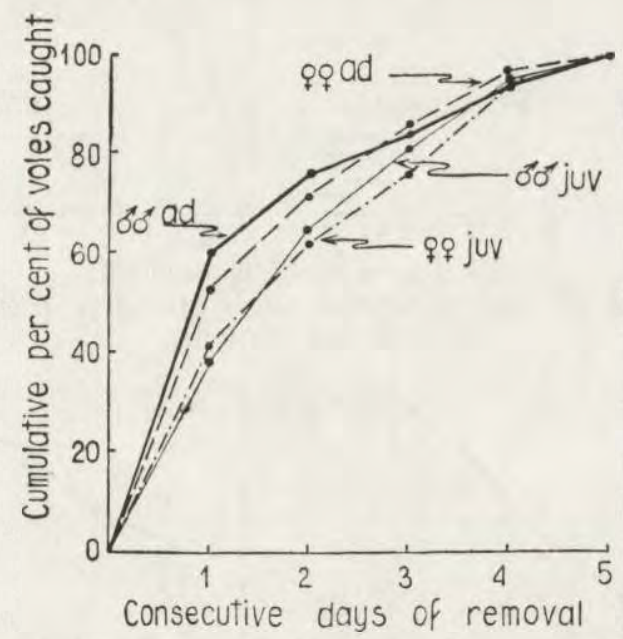

Fig. 2. Removal rate of males and females, of young and adult root voles.

Mean values of cumulative percentage for all groups of voles caught were calculated retaining the division into age and sex (Fig. 2). Differences in removal for the first three days between young females and males were $3-5 \%$, and are similar to those in adult animals $-2-7 \%$. This justifies our treating individuals of the two sexes jointly.

Greater differences were observed between young and old individuals of the same sex (Fig. 2). On the first day, for example, $38 \%$ of young males and $60 \%$ of old males were caught, and on the second day respectively 65 and $76 \%$. By the second day $72 \%$ of the old, but only $62 \%$ of the young females had been caught. This shows that there is a tendency for the old individuals to be caught more quickly, which is also clear in other combinations for different groups. 
Comparison was next made of the removal rate in snap traps and cones, grouping all SM censuses according to the type of trap whether pre-baited or not and age of animals (Fig. 3). The differences between

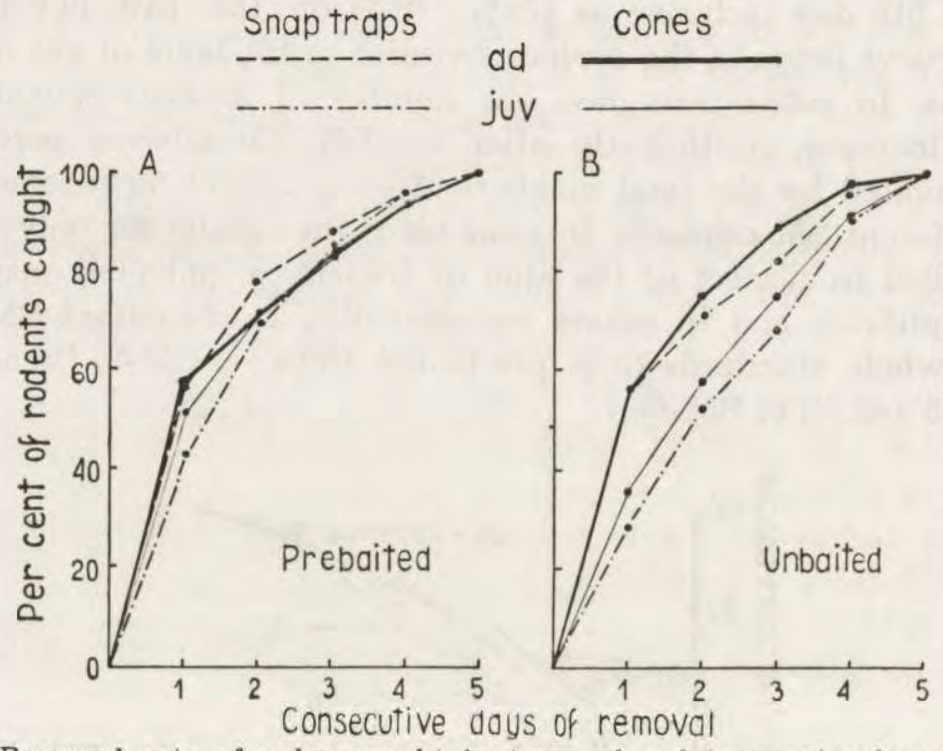

Fig. 3. Removal rate of voles caught in traps placed in previously pre-baited or unbaited stations.
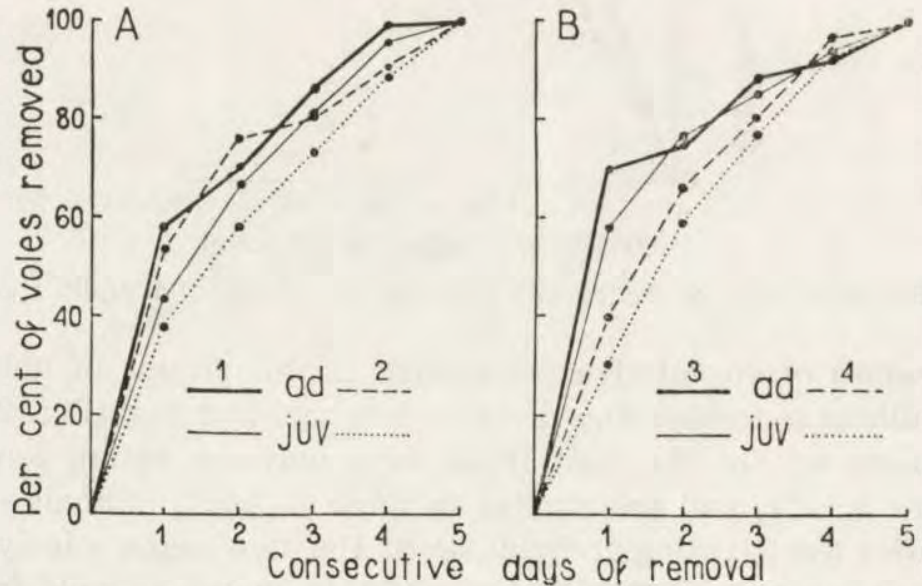

Fig. 4. Removal rate of voles caught in snap traps (A) and in pitfalls (B). Different curves show average data for all censuses during which only one $(1,3)$ or two $(2,3)$ types of traps were used.

different types of traps are so slight that it is not necessary to check for significance. It is additionally shown by this example (particularly in the combination of stations not previously baited) that old individuals are caught (removed) more quickly. 
We did not establish that there were any significant differences in the removal rate of voles with traps of a given type distributed evenly over the whole SM area, or set alternately with another type of trap (such as for instance in SM-5 and 6, Fig. 4), although young animals were caught more quickly on areas using cones only than old individuals in cones on areas with a mixture of traps (Fig. 4b).

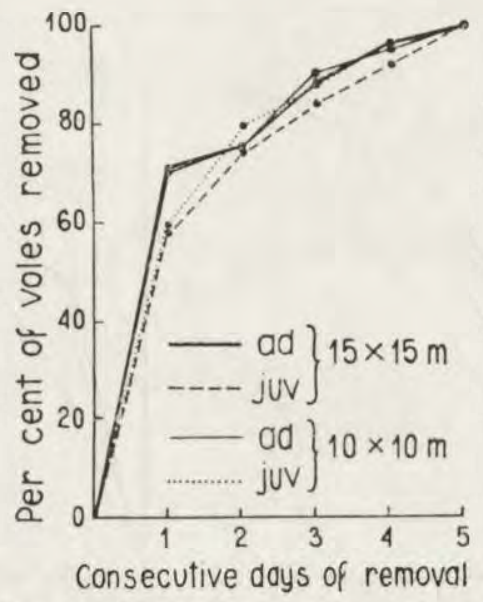

Fig. 5. Comparison of removal rate of voles caught in pitfalls arranged in a grid of $15 \times$ $15 \mathrm{~m}$. (SM 3, second half) or $10 \times 10 \mathrm{~m}$. (SM 4).

In one case (SM-4) a group of cones $10 \times 10 \mathrm{~m}$. was used in order to find out if this affects intensivity of removal. It will be seen from Fig. 5 that the differences cannot be expected to be significant.

\subsection{Influence of pre-baiting}

The removal rate of voles on pre-baited and unbaited sites is compared in Fig. 6. Snap traps show far greater differences than pitfalls but this only applies to young animals. Adult animals are caught only slightly more quickly in pre-baited snap traps. Pitfalls however, trap adult voles best when placed on sites not pre-baited. When compared with the Chi-square test, however, these differences proved not to be significant in either case. There are thus no grounds for assuming that pre-baiting increased the removal rate of voles, althoug in the case of snap traps the total numbers were increased (see below).

There are, however, distinct differences in the total numbers of voles removed in pitfalls and snap traps laid on pre-baited and unbaited stations. Capture in snap traps is almost twice as high in pre-baited than in unbaited places (Table 2), these differences being highly sta- 
tistically significant in all combinations (Chi-square test). Trapping in pre-baited pitfalls does not differ from that for pitfalls on unbaited stations. Young females are an exception: significantly more are caught in unbaited pitfalls. We do not, however, consider that there is any real

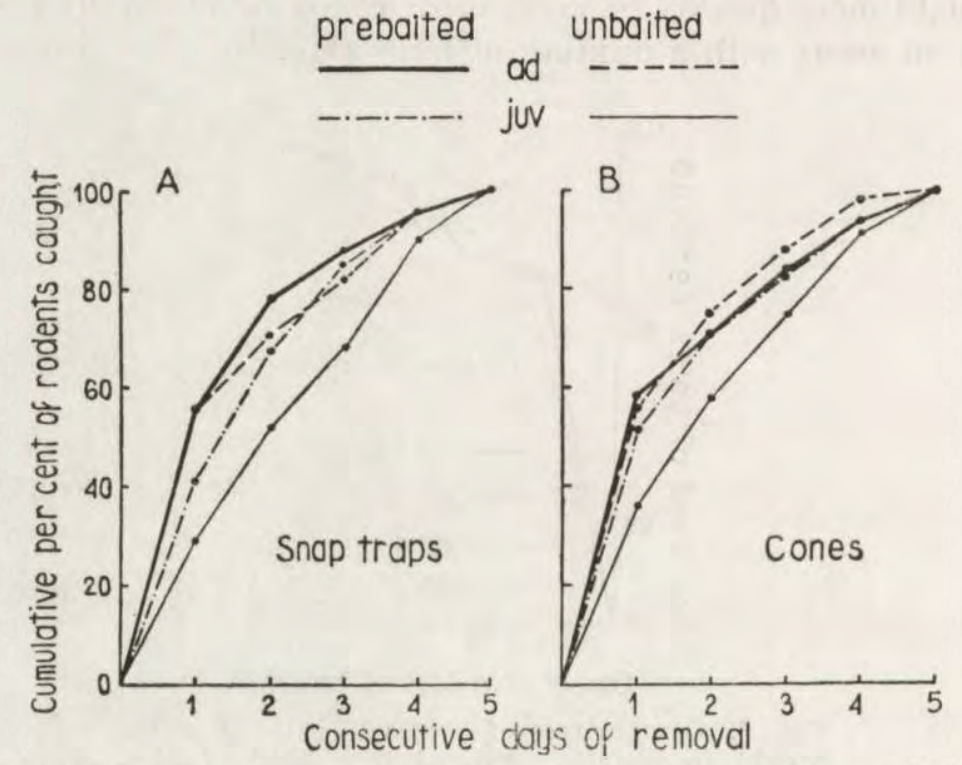

Fig. 6. Removal rate voles caught in snap traps and metal cones (pitfalls).

Table 2.

Actual numbers of $M$. oeconomus removed in two types of traps placed in prebaited $(\mathrm{p}-\mathrm{b})$ or unbaited (ub) stations. SM censuses number 5 and 6 (cf. Table 1) taken together.

\begin{tabular}{|c|c|c|c|c|c|c|c|c|}
\hline \multirow{2}{*}{ Age and sex } & \multicolumn{2}{|c|}{ Pitfalls } & \multirow{2}{*}{$\chi^{2}$} & \multirow{2}{*}{$\begin{array}{l}\text { Proba- } \\
\text { bility } \\
\text { d.f. }=1\end{array}$} & \multicolumn{2}{|c|}{ Snap traps } & \multirow{2}{*}{$\chi^{2}$} & \multirow{2}{*}{$\begin{array}{l}\text { Proba- } \\
\text { bility } \\
\text { d.f. }=1\end{array}$} \\
\hline & $p-b$ & $\mathrm{ub}$ & & & $\mathrm{p}-\mathrm{b}$ & $\mathrm{ub}$ & & \\
\hline Young, females & 78 & 110 & 5.4 & 0.02 & 66 & 41 & 5.8 & 0.02 \\
\hline Young, males & 127 & 138 & 0.4 & - & 104 & 37 & 34.0 & 0.001 \\
\hline Adult, females & 20 & 33 & 3.1 & 0.05 & 59 & 39 & 4.0 & 0.05 \\
\hline Adult, males & 18 & 20 & 0.1 & - & 19 & 6 & 6.8 & 0.01 \\
\hline Total & 243 & 295 & & & 248 & 123 & & \\
\hline
\end{tabular}

significance in this fact, although total figures show that 55 per cent of all the animals caught in pitfalls were obtained from unbaited sites. This chiefly reflects the more intensive trapping of females (young $58 \%$ and adult $62 \%$, in relation to all females in the given category). It is, however, chiefly males (74\% of young and $76 \%$ of adults) and not 
females (respectively 62 and $60 \%$ ) which account for the predominance of animals caught in baited traps.

We next took the number of individuals of one sex in one age category as $100 \%$ and calculated their percentage in each of four combinations of type of trap and baiting (Fig. 7). It was found that young individuals distinctly prefer cones, while old animals prefer snap traps, although to a lesser degree. This comparison also leads to the conclusion that the number of voles caught in cones is the same as in baited snap traps and

$$
\left.\left.\begin{array}{cc}
\text { Prebaited } \\
\text { Unbaited }
\end{array}\right\} \text { cones } \begin{array}{l}
\square \\
\text { Oo }
\end{array}\right\} \text { Snap traps }
$$

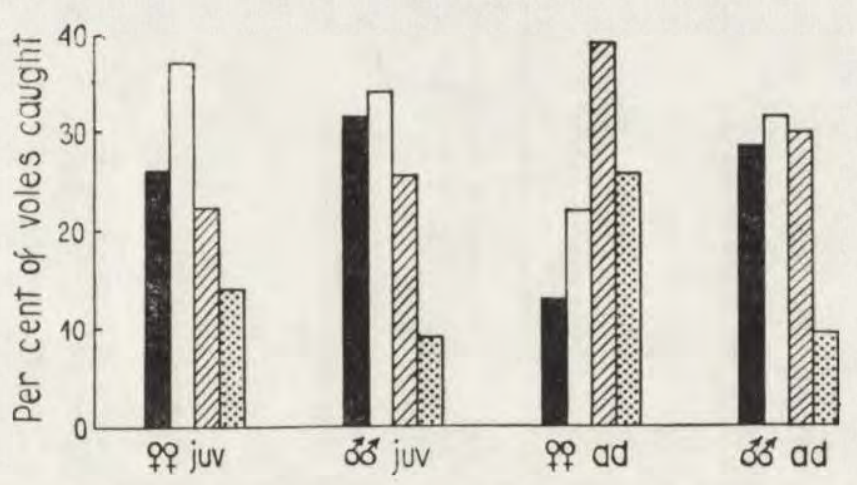

Fig. 7. Percentage distributions of voles actually caught in different types of traps (pitfalls and snap traps placed on previously pre-baited or unbaited stations). SM censuses number 5 and 6 treated jointly.

is twice as great as in unbaited snap traps. The cone pitfall is therefore (regardless of whether baited or not) just as good (or even better) a trap for the voles as a snap trap placed in a previously pre-baited site.

\subsection{Effect of time of the day on the numbers of voles removed}

In order to obtain confirmation of the initial observations pointing to differences in the number of voles caught during the night and during the day, materials for three SM censuses were compared (SM-1, SM-2, SM-6), in which the time of morning and evening inspection of the trapping service was known. Inspection was always made between $6,00-8,00$ in the morning and between $17,00-19,00$ in the evening, that is, after sunrise and before sunset. As more rodents were generally caught during the first two days than in subsequent days this division for the first days covered a 13-hour »night«, and 11-hour »day", and as from the third day - a 14-hour "night» and 10-hour »day «. 
Calculation was made of the numbers of voles caught for each hour of day and night in the sense understood above, and then the night/day index of trappability was calculated (Fig. 8).

Distinct predominance of "night « capture, which shows a tendency to increase in successive days of trapping, is observed in May and July. In autumn, on the other hand, this relationship was found only on the first day of capture. On subsequent days "day " capture predominated increasingly over "night " capture. This undoubtedly points to the fact that the activity of $M$. oeconomus varies at different times of the year.

$$
\begin{array}{ll}
\text { May, July } & \text { September } \\
\text { SM-1,2 } & \text { SM- } 6
\end{array}
$$

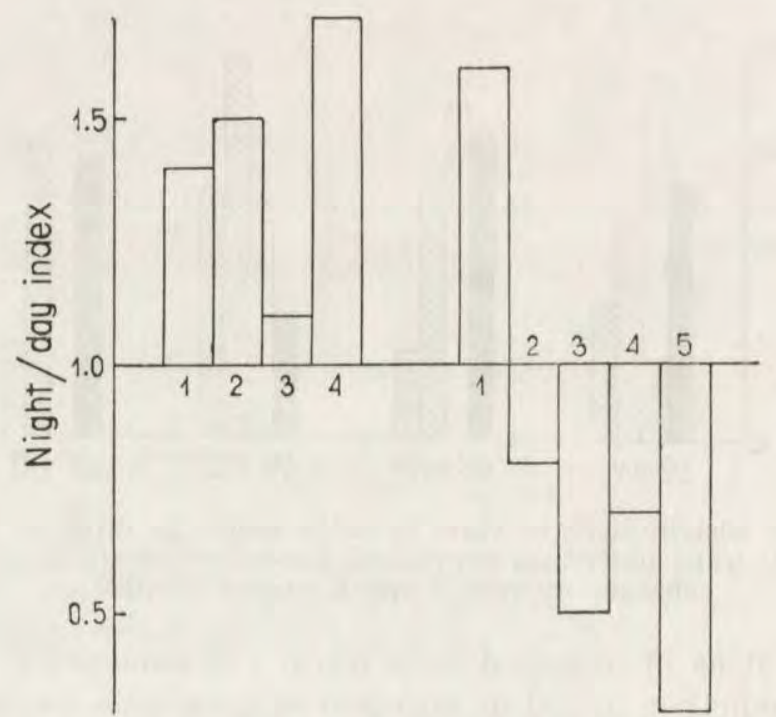

Fig. 8. Values of the night/day index of trappability. Numbers at top or botom of rectangles indicate the successive day of trapping.

The supposition that the activity of this species is intensified at dawn and dusk (Karaseeva \& Ilenko, 1957) can therefore only be confirmed by the diagram for the spring-summer period.

\subsection{Distribution of captures throughout the study area}

In order to ascertain whether prebaiting attracts voles from adjacent areas, and whether there is any entry at all of animals from outside into the SM area, comparison was made of the number of animals caught per trapping site. The centre square, covering 100 trap stations was compared with two lateral belts lying in the same plantations, from 
north and south in relation to the square and jointly containing 60 trap stations. Captures on the remaining parts of the external belt were purposely not taken into consideration, as very different habitat conditions prevailed there, which might have completely clouded the results. In SM-3 we calculated this index for both halves of the internal square (50 stations) and for the external belts corresponding to them (6 rows each containing 5 stations - 30 trap stations), thus treating the half of the SM area with both snap traps and cones separately.

The results obtained in four consecutive SM censuses (SM 3-6) in some cases point to more voles per station in the centre, and in others in the external belt. The mean values of these four standards however (centre 1.58, external belt -1.60 voles/trap station) show that these differences are not significant. It is thus clear that in the case of $M$. oeconomus we are not concerned with the entry of animals from neighbouring areas on to the SM area.

\subsection{Comparison of removal rate of $M$. oeconomus and $S$. araneus}

It can be seen from Table 1 that in addition to $M$. oeconomus, which dominates in the study area, a small numbers of other mammals were also caught (ca $9 \%$ ), most of which were Sorex araneus (L in na e us, 1758). Other species of insectivores [S. minutus ( $\mathrm{L}$ inna e us, 1766)

Table 3.

Comparison of removal rate of $M$, oeconomus and $S$. araneus (SM $-3,4,5,6$ treated jointly).

$\mathrm{n}$ - daily capture, $\%$ - cumulative per cent of animals removed till the given day.

\begin{tabular}{|c|c|c|c|c|c|c|c|c|}
\hline \multicolumn{2}{|c|}{ Day of removal } & 1 & 2 & 3 & 4 & 5 & 6 & Total \\
\hline \multirow{2}{*}{ M. oeconomus } & $\mathrm{n}$ & 693 & 294 & 200 & 187 & 105 & 45 & 1524 \\
\hline & $\%$ & 45 & 65 & 78 & 90 & 97 & 100 & - \\
\hline \multirow{2}{*}{ S. araneus } & $\mathrm{n}$ & 83 & 49 & 31 & 15 & 16 & 9 & 203 \\
\hline & $\%$ & 41 & 65 & 80 & 87 & 95 & 100 & - \\
\hline
\end{tabular}

and Neomys fodiens (Penn an t, 1771)] and also rodents [Apodemus flavicollis ( $\mathrm{Mel} \mathrm{ch}$ ior, 1834), Clethrionomys glareolus ( $\mathrm{S} \mathrm{chreber}$, 1780) and Mus musculus (L in na e $\mathrm{s}, 1758$ )] and also Mustela nivalis Linnaeus, 1766, were caught in numbers varying from $2-8$ individuals (S. minutus - 32). It was therefore held that only $S$. araneus can be taken into consideration in any eventual comparisons. 
Comparison was made for the whole material from 4 censuses treated jointly (SM 3-6) of the removal rate of M. oeconomus $(n=1524)$ and Sorex araneus $(\mathrm{n}=203)$ during the first 6 days of trapping (Table 3).

The results presented indicate that cumulative percentages of individuals of both species caught on successive days differ very slightly. In addition when considered both as a whole and in different censuses (particularly when pitfalls were used) the results show distinct decrease in the number of shrews caught. This observation confirm earlier data obtained by A ulak (1967) for forest ecosystems in the Białowieża National Park, and points to the possibility of using the method of intensive removal for estimating the number of Soricidae also.

\section{EFFECT OF THE SIZE OF THE STUDY AREA ON NUMBER OF VOLES REMOVED PER TRAP STATION}

Calculations were made in a similar way to that described above (for the number of voles caught per trap station) for the smallest central square measuring 0.36 ha (16 trap stations), and for increasingly larger

Table 4.

Effect of the size of the study area on number of voles removed per trap station. Results for smaller areas than whole SM were obtained by substracting external belts of one, two, etc. rows of trap stations.

\begin{tabular}{|c|c|c|c|c|c|c|c|c|}
\hline \multirow{2}{*}{$\begin{array}{c}\text { Area, } \\
\text { ha }\end{array}$} & \multicolumn{7}{|c|}{ C E N S U S N U M B E R } & \multirow{2}{*}{ Avg. } \\
\hline & 1 & 2 & 1 st $\stackrel{3}{\text { half }}$ & 2nd $\stackrel{3}{\text { half }}$ & 4 & 5 & 6 & \\
\hline 0.36 & 2.19 & 3.25 & 0.75 & 3.38 & 1.39 & 1.31 & 2.19 & 2.06 \\
\hline 0.81 & 1.80 & 3.94 & 0.94 & 2.67 & 1.32 & 1.86 & 2.28 & 2.12 \\
\hline 1.44 & 1.81 & 398 & 0.75 & 2.47 & 1.19 & 1.64 & 1.98 & 1.96 \\
\hline 2.25 & 1.80 & 3.71 & 0.98 & 2.42 & - & 1.75 & 1,63 & 1,91 \\
\hline 2.53 & - & - & - & - & 1.07 & - & - & 1.91 \\
\hline 3.24 & 1.68 & 3.49 & 0.89 & 2.25 & - & 2.05 & 1.74 & 2.01 \\
\hline 4.41 & - & - & - & - & - & 2.01 & 1.59 & - \\
\hline 5.76 & 1.26 & 3.48 & 0.75 & 2.11 & - & 2.21 & 1.54 & 1.89 \\
\hline
\end{tabular}

areas, moving outwards from the centre and adding one row of traps each time. In SM-3 we proceeded as before giving the result from rectangles increasing outwards from the centre of the whole area, which were contiguous with each other along the median line. Results for successive SM-censuses are given in table 4. A tendency is observed to stabilisation of this index within limits of area size from 0.81 to 3.24 
ha. Greater deviations were found with smaller areas (0.36 ha) and larger areas, and in particular - the whole square. Mean values, although calculated only from a maximum number of 6 samples, emphasise the constant character of the trapping result per station.

\section{ESTIMATION OF NUMBERS OF VOLES}

The numbers of $M$. oeconomus were estimated from the regression equation ( $\mathrm{H}$ a y ne, 1949; Grodziński et al., 1966) always for the first 5 trapping days (Table 5). These estimates are in close agreement with the numbers of voles actually removed during the same period of time.

Table 5.

Estimation of $M$. oeconomus number using regression method and truncated distribution method ( $\mathrm{J}$ a n i o n et al., 1968) as compared with numbers removed during 5 days, and whole catching periods. Numbers underlined are the closest to the numbers of voles actually removed during a 5-day period.

\begin{tabular}{|c|c|c|c|c|c|c|c|c|}
\hline \multirow{2}{*}{ Method of calculation } & \multicolumn{7}{|c|}{ C E N S U S N U M B E R } & \multirow{2}{*}{$\begin{array}{l}\text { Avg. } \\
1-6\end{array}$} \\
\hline & $1^{*}$ & 2 & 1st half & 2nd half & 4 & 5 & 6 & \\
\hline $\begin{array}{l}\text { Actually removed } \\
(\text { Total N) }\end{array}$ & 324 & 888 & 88 & 275 & 271 & 570 & 394 & 401 \\
\hline $\begin{array}{l}\text { Actually removed } \\
\text { ( } 5 \text { days only) }\end{array}$ & 324 & 756 & 67 & 237 & 230 & 570 & 376 & 366 \\
\hline $\begin{array}{l}\text { Estimated } N \text { (regres- } \\
\text { sion for } 5 \text { days) }\end{array}$ & 376 & 933 & 71 & 228 & 226 & 616 & 456 & 415 \\
\hline $\begin{array}{l}\text { Estimated } N \text { (truncated } \\
\text { distribution, } 1-5 \text { days }\end{array}$ & 393 & $\underline{922}$ & 76 & $\underline{250}$ & $\underline{234}$ & 642 & 452 & 424 \\
\hline $\begin{array}{l}\text { Estimated } N \text { (truncated } \\
\text { distribution, } 1-3 \text { days) }\end{array}$ & $\underline{324}$ & 1042 & $\underline{58}$ & 209 & 211 & $\underline{528}$ & $\underline{449}$ & 403 \\
\hline $\begin{array}{l}\text { Estimated } N \text { (truncated } \\
\text { distribution, } 3-5 \text { days) }\end{array}$ & 394 & 1649 & 77 & 219 & 144 & 643 & 466 & 513 \\
\hline $\begin{array}{l}\text { Estimated } N \text { per ha } \\
\text { (regression, } 5 \text { days) }\end{array}$ & 56 & 131 & 23 & 82 & 91 & 99 & 65 & - \\
\hline
\end{tabular}

* exceptionally 4 days only.

Parallel to this we estimated the numbers of voles from truncated distributions (Janion et al., 1968) for periods of the first five, first three and last three days of trapping. Table 5 shows that numbers estimated from truncated distributions for the first three (or first five 
days) are very similar to those actually removed over the whole period, and also to those estimated from the rectilinear regression equation for the first 5 days. Estimates for the final period markedly exceed the above mentioned ones. It must be concluded from this that the likelihood of trapping voles alters during the final period.

Fig. 9 shows two range examples of differences which may exist among different estimates of the root vole numbers. Mean estimates,
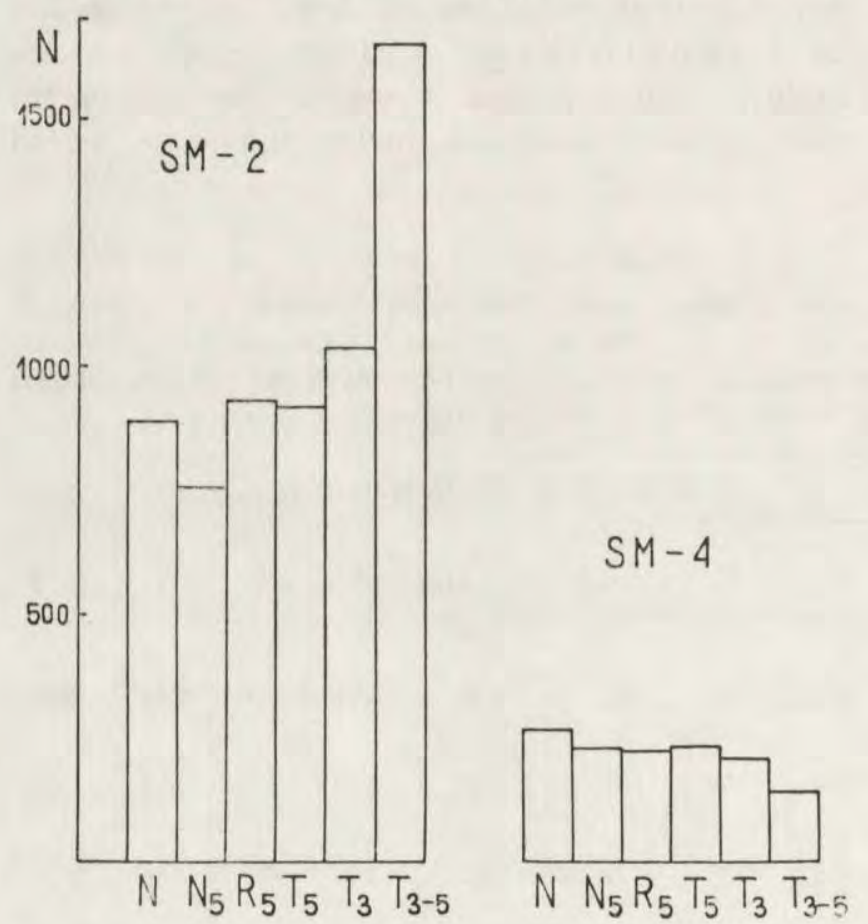

$$
S M-1-6
$$

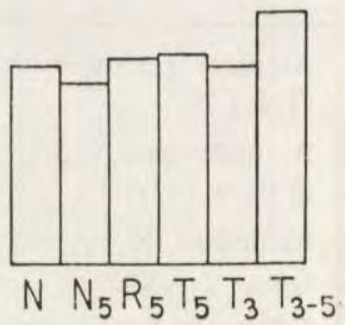

Fig. 9. Comparison of estimates of the root vole numbers obtained by different methods. There are given two examples (SM-2 and SM-4) as well as average data for all six SM censuses. $\mathrm{N}-$ Number of voles actually removed, $\mathrm{N}_{5}-$ Number of voles caught during first 5 days, $R_{5}-$ Number estimate from linear regression equation, for 5 days. $\mathrm{Td}_{5}, \mathrm{Td}_{3}, \mathrm{Td}_{3-5}-$ Numbers estimated using truncated distribution for first five, tree, or last tree days, respectively.

as calculated only for all six censuses, from rectilinear regression equation closely agree with those obtained from truncated distribution for first three days, or with total number of voles removed (cf. also Table 5). This point out that both methods may be equally as succesfully used for such calculations.

The number of voles in the study area estimated in this way was fairly high and during the summer reached 130 individuals per ha (Table 5). 
It is possible to compare removal rate and estimates of the density of voles caught in two types of traps (pitfalls, snap traps), set out evenly in two combinations (in pre-baited and unbaited places) (Table 6). Although removal rate (expressed by coefficient of regression) was similar, in unbaited places almost 2.5 times more voles per hectare were caught in pitfalls than in snap traps. Differences were smaller in pre-baited stations and were not significant. This leads to the conclusion

Table 6.

Differences between coefficients of regression and estimations of voles abundance calculated from rectilinear regression equation for 5 days $\left(R_{5}\right)$. (SM censuses nos. 5 and 6 taken together).

\begin{tabular}{|l|l|c|c|c|c|c|}
\hline Character & Method & Snap traps & Pitfals & $\chi^{2}$ & $F$ & Diff.* $^{*}$ \\
\hline $\begin{array}{c}\text { Coefficient } \\
\text { of } \\
\text { regression }\end{array}$ & Pre-baited & -0.380 & -0.302 & - & 1.085 & - \\
\cline { 1 - 5 } & Unbaited & -0.311 & -0.325 & - & 0.026 & - \\
\cline { 1 - 3 } of & Pre-baited & 46 & 49 & 0.095 & - & - \\
voles $\left(\mathrm{R}_{5} / \mathrm{ha}\right)$ & Unbaited & 24 & 59 & 14.759 & - & + \\
\hline
\end{tabular}

* Differences are significant $(+)$ or not significant $(\rightarrow)$ at $P=0.05$.

that different estimates of population density can be obtained in the same study area depending on the kind of trap, even when the removal rate of individuals is nearly uniform.

\section{DISCUSSION}

The removal method for taking censuses of small mammals assumes that during the period of studies individuals of different categories have the same chances of being caught, and variations in population numbers due to natality, mortality and migration do not occur. In practice however it is impossible to eliminate the effect of these factors. Their action can only be reduced (perhaps to within acceptable limits) by shortening of the period of removal of the mammals from the study plot as much as possible. The problem then arises as to what procedure is possible in relation to the root vole; in other words, is the rate and effectiveness of removal sufficiently great to ensure that the results obtaned are reliable? Let us therefore consider some aspects of the operation of the removal method.

Each of the two types of traps we used (snap traps, pitfalls) records not only different absolute numbers of voles caught but also different 
proportions of their various categories (age, sex, etc.). Pre-baiting during the period proceding removal does not affect the removal rate or the number of voles caught using pitfalls. Pre-baiting, however exerts a distinct effect in the case of snap traps, although to lesser degree than on forest rodents (cf. e. g. Grodziński et al., 1966). Our results thus indicate that pitfalls, whether placed on previously baited sites or not, are equally effective as snap traps on pre-baited sites. Adult individuals, particularly males which have a larger home range than adult females ( $\mathrm{T}$ a s $\mathrm{t}, 1966$ ), predominate in captures made using snap traps, while more young males are caught in pitfalls. Our results also show that different types of traps record different population densities of voles (cf. Table 6).

That phenomena of this kind are certainly general in character can be gathered from observations, if few, made by other authors. For instance $\mathrm{Che} \mathrm{kk}$ owska (1967) observed differences in the trappability of young, old, resident and migrating individuals, particularly during the reproductive period, both within the species and between species, in the case of two rodents - Clethrionomys glareolus ( $\mathrm{S} \mathrm{chr}$ e ber, 1780 ) and Apodemus agrarius ( $\mathrm{P}$ a ll a s, 1771), caught by means of live traps and pitfalls.

Similarly in current studies on the survival of $C$. glareolus under natural conditions (P ucek, Ryszkowski \& Zejda, in press) it has been found that the average length of live calculated for animals caught in pitfalls is shorter than those caught in live and snap traps. This is undoubtedly due to the apparent differences in the population structure of these rodents produced by the two main types of trap. Without discussing the probable mechanisms which influence these results, we must conclude that depending on the trapping method used the estimates of the energy flow through rodent populations will differ.

Some data on the thoroughness of removal were obtained in two cases, when removal lasted 8 and 10 days (SM-3, SM-4). In these cases we found that daily captures decreased almost to zero from the 6 - 8 th day, after which a sharp increase occured. The table below illustrates the numbers of voles caught on successive days:

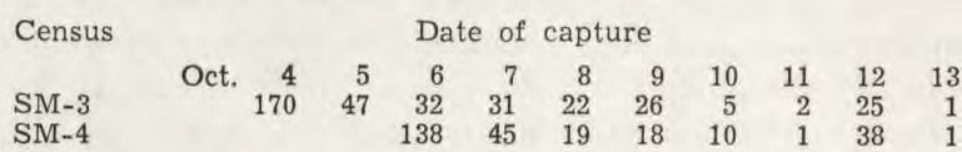

In both cases the sharp rise in the number of voles caught took place after rainfall, which usually results in an increase in captures (S i d orowicz, 1969; Mystkowska \& Sidorowicz, 1961; Gentry, 
Golle y \& Mc Ginnis, 1966). This was however immediately followed by a decrease in daily capture to the level proceding the increase.

There are probably two possibilities here: (1) Some of the voles did not appear during removal (e.g. trap-shy animals), or (2) This increase is caused by intensified immigration of rodents from surrounding area. We analysed the distribution of voles caught after rain. In both cases (the neighbouring study areas were in operation at the same time) they were young animals, and spread throughout the whole study areas. We incline to the opinion that they were individuals which quickly entered the trapping area as the result of increased activity following rainfall. The decrease in daily capture practically to zero on the day after the rainfall, and also the relatively small percentage of animals appearing after rain in relation to the total number removed during the whole period (SM-3 -7 per cent, SM- $4-14$ per cent) suggests that the removal method can be used for making a relatively accurate estimate of the number of root voles, and that the duration of the removal period can be (and should be) shortened to 5-6 days. A similar removal period was suggested for forest rodents by G rodziński et al. (1966) and A u lak (1967). Another argument against prolonging the removal period is also that likelihood of capture decreases during the final days (e. g. 3-5), as is shown both by our data (cf. p. 475) and by the earlier observations of other authors (Ryszkowski, Andrzejewski \& Petrusewicz, 1966; Janion, Ryszkowski \& Wierzbowska, 1968).

Gentry, Golley \& Smith (1968) found that some species of rodents and insectivores do not reveal their presence until the later days of a 27-day capture period in a cove hardwood forest in South Carolina (U.S.A.). Individuals of these species formed e.g. 17, 10 and smaller percentage of the total catch $(\mathrm{N}=124$ of small mammals). In addition insectivores dominated there ( 66 per cent), to which, as is known from the study by A u lak (1967), the removal method cannot always be applied, as a decrease in the daily catch is not always obtained on consecutive days of removal. In our particular case we obtained rapid removal of insectivores (Sorex araneus dominating), almost identical to the removal rate of voles (Table 3). It would however appear that this may have been due to the "non-forest « local conditions and the still relatively low abundance of shrews in this area.

Thus the appearance or non-appearance of insectivorous mammals, and also rodents occurring in low densities in the given area and reacting differently to the given type of trap and bait, can be decisive in question of the suitability of the removal method for estimating their numbers. In view of the possibility of rodents rapidly entering the 
study area (e.g. after rain), we do not think that the data obtained by Gentry et al. (l.c.) justified these authors' suggesting prolongation of the removal period.

In summing up it seems to us that the removal method may be applied for defining the density of the root vole, and most probably also for other species of rodents with a similar relation to traps, bait and with similar biology. On the basis of the results obtained it may be suggested that some modifications of the SM method should proceed in the following directions: (1) Depending on the soil properties conical pitfalls (without pre-braiting) can be used just as successfully as pre-baited snap traps. This shortens the census period to the removal phase only. (2) Removal for a 5-day period from a 1-ha area is sufficient, in view of the fact that immigration into the study area was not usually found and that the number of animals per trap station is constant throughout the whole study area.

Consideration of these questions on the basis of our results, and also the data so far published by other authors, leads to the following suggestions for future studies on improving the SM method and for interpreting the results obtained:

(1) The SM method has proved not to give absolute results, but to give density estimates far more accurate than other methods of capturing mammals used so far. In relation to different species it may over (cf. e.g. A ulak, 1967; Ryszkowski, in press) or under-estimated.

(2) The operation of the removal method should be tested in a comparable way for other species of Micromammalia, paying special attention to such important factors as: the relation of the given species to kind of trap and bait, the size of the removal area, distribution of the grid of traps etc. It is only by obtaining more extensive comparable material that it is possible to estimate whether and under what condiions the removal method can be applied to estimating the density of different species of mammals. The positive results obtained so far for forest and meadow rodents (mice, voles) are not of course sufficient to permit their general application to all form of small mammals.

Acknowledgement: Authors wish to express their gratitude to Mr. Anthony $\mathrm{C}$ heke of Edward Grey Institute, Oxford, for reading of the manuscript and valuable corrections of the text, and Dr. S. Ostrowski and Engr K. Mierzwińs $\mathrm{i}$ for making it possible to carry out these studies in Forestry Research Institute study area.

\section{REFERENCES}

1. A u lak W., 1967: Estimation of small mammal density in three forest biotopes. Ekol. pol. A., 15, 39: 755-778. 
2. Buchalczyk T., 1967: Usefulness of the intensive removal method in estimating the density of Microtus oeconomus (Pallas, 1776). Small Mamm. Newslett., 1, 3: 14-15. Warszawa.

3. Chelk ow \$ka H., 1967: An attempt at comparing two methods of trapping small rodents (in pitfalls and live traps). Ekol. pol. A., 15, 40: 779-785.

4. De Lur y D. B., 1947: On the estimation of biological populations. Biometrics, 3: $145-167$.

5. Gentry J. B., Golle y F. B. \& Mc Ginnis J. T., 1966: Effect of weather on the captures of small mammals. Amer. Midl. Naturalist, 75: 526-530.

6. Gentry J. B., Golle y F. B. \& Smith H. M., 1968: An evaluation of the proposed International Biological Program census method for estimating small mammal populations. Acta theriol., 13, 18: 312-328.

7. Gębczyńska Z., 1967: Energy budget of Microtus oeconomus (Pallas, 1776) at different seasons. Small Mamm. Newslett., 1, 3: 7.

8. Grodziński W., Pucek Z. \& Ryszkowski L., 1966: Estimation of rodent numbers by means of prebaiting and intensive removal. Acta theriol, 11, 10: 297-314.

9. Hayne D. W., 1949: Two methods for estimating population from trapping records. J. Mamm., 30: 399-411.

10. Janion M., Ryszkowski L. \& Wierzbowska T., 1968: Estimate of number of rodents with variable probability of capture. Acta theriol., 13, 16: $285-294$.

11. Karaseeva E. V. \& I l'e n ko A. I., 1957: Nekotorye osobennosti biologii polevki-ekonomki izučennye metodom mečenija zver'kov. (in "Fauna i ekologija gryzunov«) Materialy po gryzunam, 5: 171-184. Mosk. Obšč. Isp. Prir., Izd. Mosk. Univ., Moskva.

12. Mystkowska E. T. \& Sidorowicz J., 1961: Influence of the weather on captures of Micromammalia. II. Insectivora. Acta theriol., 5, 18: 263-273.

13. Pucek Z., Ryszkowski L. \& Zejda J., in press: Estimation of average length of life in Bank vole. [In Energy flow through small mammal populations, Eds.: Petrusewicz K., Ryszkowski L. \& H. N. Southern]. Państw. Wyd. Nauk., Warszawa.

14. R y szkowski L., in press: Operation of standard minimum method. Ibidem.

15. Ryszkowski L., Andrzejewski R. \& Petrusewicz K., 1966: Comparison of estimates of numbers obtained by the method of release of marked individuals and complete removal of rodents. Acta theriol., 11, 12: $329-342$.

16. Ryszkowski L. \& Petrusewicz K., 1967: Estimation of energy flow through small rodent populations. [In $»$ Secondary productivity of terrestrial ecosystems«, Ed. Petrusewicz K.]. Państw. Wyd. Nauk., 1: 125-146. Warszawa-Kraków.

17. Sidorowicz J., 1960: Influence of the weather on captures of Micromammalia. I. Rodents (Rodentia). Acta theriol., 4, 9: 139-158.

18. T a s t J., 1966: The root vole, Microtus oeconomus (P a 11 a s), as an inhabitant of seasonally flooded land. Ann. Zool. Fenn., 3: 127-171.

Received, October 5, 1968.

Mammals Research Institute,

Polish Academy of Sciences,

Białowieża, Poland. 


\section{Tadeusz BUCHALCZYK i Zdzisław PUCEK}

\section{OCENA LICZEBNOS̃CI MICROTUS OECONOMUS METODA STANDARD MINIMUM}

\section{Streszczenie}

W uprawach leśnych, liściastych, iglastych i mieszanych, posadzonych na zmeliorowanym torfowisku wysokim w Puszczy Augustowskiej, dokonano sześciokrotnie oceny zagęszczenia izolowanej populacji nornika północnego metodą wyłowu. Oryginalną metodę Standard Minimum (Grodziński, Pucek i Ryszkow$\mathrm{ski}$, 1966) nieco zmodyfikowano, skracając niekiedy okres przynęcania do 3 dni, a wyłowu do 4-5 dni oraz używając pulapek zatrzaskowych na równi ze stożkami (po jednym w każdym punkcie). Dla poznania wpływu przynęcania norników dwie ostatnie oceny przeprowadzono używając pułapek i stożków, ustawionych na przemian $\mathrm{w}$ miejscach uprzednio przynęcanych i nieprzynęcanych.

Stosunek $M$. oeconomus względem wykładanej przynęty jest inny niż gryzoni leśnych; nigdy nie osiągano bowiem 100-procentowego jej wykorzystania (Ryc. 1).

Brak różnic w tempie wyłowu samców i samic, lecz istnieje wyraźna tendencja do szybszego wyławiania się starych osobników obu płci (Ryc. 2). Nie ma istotnych różnic $w$ tempie wyłowu norników w różne typy pułapek, ani też $w$ pułapki w punktach zakarmianych i niezakarmianych (Ryc. 3-6).

Całkowita ilość norników złowionych w zatrzaski zakarmiane jest prawie dwukrotnie większa niż $w$ niezakarmiane i w przybliżeniu taka sama jak w stożki, obojętnie zakarmiane czy nie (Tabela 2). Ponadto osobniki młode wyraźnie preferują stożki, a stare - zatrzaski (Ryc. 7). Tempo wyłowu ryjówek było na badanym terenie bardzo zbliżone do wyłowu norników (Tabela 3 ).

Nie stwierdzono nachodzenia norników z poza powierzchni wyłowu. Liczba norników na jeden punkt była przeciętnie niemal identyczna w centrum jak i na pasie zewnętrznym (odpowiednio 1,58 i 1,60 ). Ponadto ilości norników na jeden punkt odłowu $\mathrm{w}$ centralnym kwadracie 0,81 ha były bardzo zbliżone do takichże wskaźników, wyliczonych z kolejnych większych kwadratów, postępując od centrum aż do kwadratu o powierzchni 3,24 ha (Tabela 4).

Liczebność norników oceniono z równania regresji prostoliniowej oraz metoda rozkładów uciętych, wykazując dużą zgodność tych metod, już przy średnich dla 6 standardów (Tabela 5, Ryc. 9). Maksymalne zagęszczenie norników na badanym terenie osiągało latem 130 osobników na hektar. Jednakże oceny uzyskane z zatrzasków w miejscach nie przynęcanych były 2,5 raza większe niż ze stożków. W miejscach przynęcanych różnice te były niewielkie (Tabela 6).

Autorzy szeroko dyskutują mechanizm działania metody Standard Minimum i dochodza do następujących wniosków: (1) Intensywny wyłów ssaków z powierzchni badawczej daje naogól zadawalające wyniki, umożliwiają ocenę zagęszczenia gryzoni leśnych i ląkowych (myszy, norniki) a niekiedy nawet i owadożernych (ryjówki). (2) Działanie metody względem innych gatunków ssaków winno być sprawdzane $\mathrm{w}$ sposób zunifikowany, $\mathrm{z}$ uwzględnieniem działania tak ważnych czynników jak: stosunek danego gatunku do rodzaju pułapki i przynęty, wielkość powierzchni wylowu, zagęszczenie sieci pułapek, itp. Uwzględnienie wpływu tych czynników ważne jest również przy interpretacji uzyskiwanych wyników. 